describes its relationship with existing groups. "While the work of these groups provides an essential base of information and documentation," it says, "the missing element has been a force unlimited in scope and unfettered by tax prohibitions... No organisation has set out to mobilise existing resources to take hard political action on the critical measures which must be implemented to relieve the problems which now disrupt all economies, undermine political stability, suppress human freedoms, and directly threaten human survival throughout the world. Our purpose is to build such an organisation".

The idea is that New Directions will work closely with other groups-indeed, many of them have representatives on the organisation's governing board-and draw heavily on their research and expertise. It will select issues to lobby for, try to bring together informal coalitions of groups to work on them, and serve as a coordinating centre for exchange of relevant information. But its chief role will be to draw as much attention as possible to global problems and their potential solutions, through direct lobbying with members of Congress, government officials, corporate executives and so on. It will also take its case to the news media, organise local groups, go to court when necessary, and provide direct support to candidates for political offices.

Clearly, although the organisation will derive much of its influence from its star-studded cast of backers and officials, the crucial factor in its effectiveness will be the size of its membership. Politicians tend to listen more attentively to messages delivered by groups backed by large numbers of voters or by large amounts of cash which can be used for campaign support. If New Directions can succeed in attracting hundreds of thousands of members, its voice will be heard above the general background noise in Washington.

At this point, however, it is difficult to predict whether or not the organisation can count on that level of support. The people most likely to join are probably already members of existing groups such as Common Cause, and it remains to be seen whether the depth of their concerns extends to spending another $\$ 25$. But there is at least one promising indication: the planning committee decided to go ahead only after a survey by a New York market research firm found considerable support for the goals of the organisation.

Another potential problem for the organisation is that unless it treads carefully, it may end up stepping on the toes of existing bodies which are already concerned with global problems

\section{FDA's aerosol ban}

IN a statement which caught most observers here completely by surprise, the Food and Drug Administration (FDA) announced last week that it intends to phase out the use of chlorofluoromethanes (so-called fluorocarbons) as propellants in many types of aerosol sprays. Although the statement did not say when the ban would take effect, or how it would be implemented, FDA said that it would begin by requiring warning labels to be placed on aerosols containing fluorocarbons, and that the ban would be imposed in an "orderly" manner.

The agency's action is surprising since it follows hard on the heels of a major report by a committee of the National Academy of Sciences which recommended that regulation of fluorocarbons should be delayed for up to two years to allow time for more research on the mechanism by which fluorocarbons are believed to be breaking down the ozone layer. The academy report suggested that since the rate of destruction of the ozone layer is small, a two-year delay in regulation would present little additional hazard.

Dr Alexander M. Schmidt, the Commissioner of FDA, said last week, however, that additional research would narrow the range of uncertainty in the calculations of ozone depletion but it "won't change the ultimate regulatory situation". He argued that "given the effects on human health even a $2 \%$ ozone depletion from 'unessential' uses of fluorocarbons is undesirable".

"The known fact", Schmidt said, "is that fluorocarbon propellants primarily used to dispense cosmetics are breaking down the ozone layer. Without remedy, the result could be profound adverse impact on our weather and on the incidence of skin cancer in people. It's a simple case of

- such as the United Nations Association, the Overseas Development Council and the Worldwatch Institute. A check with people from some existing groups last week, however, found little fear that New Directions would steal their thunder or interfere with their goals. In fact, most welcomed the possibility of having a heavyweight group fighting for their causes.

Some supporters of New Directions also argued last week that one of the organisation's chief assets is the fact that it is headed by Russell Peterson. A PhD chemist who worked for DuPont for 26 years, Peterson is a negligible benefit measured against possible catastrophic risk".

FDA's authority extends over foods, drugs and cosmetics. Thus, in theory, if has the power to regulate the formulation of products such as hair sprays and anti-perspirants which account for the bulk of aerosol uses of fluorocarbons. According to FDA's statement, the agency has authority over about $80 \%$ of all products now packaged in aerosol containers.

Schmidt said that FDA will publish details of its proposal to require labelling of aerosols containing fluorocarbons in mid-November, and that details of the phase-out programme will follow a few weeks later. The labelling programme itself should reduce consumption of fluorocarboncontaining products, and it will also help discourage stockpiling.

A spokesman for the DuPont company, the chief manufacturer of fluorocarbons, said last week that he was "astounded" by FDA's decision. The industry had regarded the academy's report as a victory because, in recommending a two-year delay in regulation, the academy had essentially backed the industry's argument that more research is needed to settle scientific uncertainties.

The industry is unlikely to take FDA's action lying down. Although industry spokesmen would not say last week how they expect to contest the ban, it is likely that they will ask for public hearings and, if necessary, go to court to prevent FDA putting its proposals into effect. One possible legal challenge may involve whether or not FDA has the authority under existing laws to take such action. The intensity of the industry's reaction will depend largely on how much time FDA gives it to phase out use of fluorocarbons, however, and that won't be known until towards the end of the year.

Republican who built a good reputation during his term as Governor of Delaware between 1969 and 1973. Peterson also knows his way around the Washington power structure very well, having served as chairman of the President's Council on Environmental Quality for three years. During that time, he took several independent stands, the latest of which was to call for immediate regulation of fluorocarbons in aerosol sprays. As one observer put it last week, a Republican, a former governor, and a former top adviser to the President are good credentials for a lobbyist. 